\title{
RECENZJE
}

„Studia Wyborcze”, tom 32, 2021

DOI: https://doi.org/10.26485/SW/2021/32/7

\section{MAGDALENA MUSIAŁ-KARG, ELEKRONICZNE GŁOSOWANIE W OPINIACH POLAKÓW. POSTAWY I POGLĄDY NA TEMAT E-VOTING, Wydawnictwo Naukowe Wydziału Nauk Politycznych i Dziennikarstwa Uniwersytetu im. Adama Mickiewicza w Poznaniu, Poznań 2020, ss. 252}

Autorka recenzowanej książki, prof. UAM dr hab. Magdalena Musiał-Karg, politolożka i ekonomistka z wykształcenia, od kilkunastu lat prowadzi zaawansowane badania nad demokracją bezpośrednią oraz wykorzystaniem nowych technologii w systemach demokratycznych ze szczególnym uwzględnieniem procesów wyborczych (e-voting). Jej opracowania monograficzne, prace zbiorowe pod redakcją, liczne studia i artykuły w akademickich wydawnictwach zbiorowych i renomowanych czasopismach naukowych (w tym zagranicznych), stanowią istotny dorobek badawczy politologii, bardzo wysoko oceniany przez środowisko akademickie i określone kręgi elit politycznych. Zdobyta wiedza z tego obszaru badawczego, wraz z umiejętnościami metodologicznymi i z perfekcją stosowanych technik badawczych, predestynowały autorkę do zmierzenia się z przeprowadzeniem analizy na temat poglądów i deklarowanych postaw Polaków dotyczących elektronicznego głosowania, a ściślej rzecz ujmując głosowania za pośrednictwem Internetu, rozpatrywanych z perspektywy różnych zmiennych o charakterze demograficznym i politycznym.

Problematyka szeroko rozumianej elektronicznej demokracji i elektronicznego głosowania wprawdzie coraz częściej inspiruje polskich naukowców (m.in. Izabela Kapsa, Elżbieta Kużelewska, Natasza Lubik-Reczek, Krzysztof Skotnicki, Andrzej Stelmach), ale polskie prace stanowią dopiero początek eksploracji nad zastosowaniem nowoczesnych technologii w procedurach wyborczych.

Magdalena Musiał-Karg dostrzegła konieczność przeprowadzenia pogłębionych studiów nad ewolucją elektronicznych form sprawowania władzy oraz wykorzystaniem Information and Communication Technologies (ICT) 
w mechanizmach decyzyjnych. Recenzowana książka wypełnia istniejącą dotychczas lukę i stanowi przyczynek do dalszych badań nad wpływem technologii informacyjnych i komunikacyjnych na procedury wyborcze. Ponadto M. Musiał-Karg, odwołując się do wyników badań własnych przedstawionych w ośmiu publikacjach autorskich (pięć) i współautorskich (trzy), ukazała wkład w rozwój teorii i stanu naukowej wiedzy dotyczącej e-votingu.

Praca autorki wpisuje się w nurt rozważań dyskusji de facto ożywionej w wyniku pandemii COVID-19 i stanowiącej akcelerator działań zmierzających do wdrożenia e-głosowania. Problematyka skonkretyzowana w tytule recenzowanej publikacji stanowi rzetelnie przeprowadzoną analizę i wieloaspektową narrację. Badanie postaw i opinii Polaków na temat $e$-votingu jest uzasadnione, ponieważ polskie prawo nie przewiduje możliwości głosowania przez Internet w wyborach, a w polskiej debacie publicznej stosunkowo rzadko podejmowana jest ta kwestia. M. Musiał-Karg podkreśla, iż „w Polsce - praktycznie do roku 2020 nie odbyła się żadna poważna dyskusja na temat głosowania elektronicznego. Potwierdza to także analiza przekazów medialnych [...] (s. 44-45). Autorka wskazuje, że: „Jednym z niezwykle istotnych narzędzi e-demokracji (będących jednocześnie wyrazem realizacji zasady zwierzchnictwa narodu) jest głosowanie elektroniczne. To innowacyjne narzędzie udziału w wyborach i referendach jest coraz częściej dyskutowanym rozwiązaniem w wielu państwach Europy i świata. Idea wdrożenia e-voting (szczególnie w formie zdalnego głosowania przez Internet) stała się popularna w wielu państwach jako naturalne następstwo rozwoju technologicznego i procesów cyfryzacji” (s. 11). „Głosowanie elektroniczne nie jest zagadnieniem szczególnie popularnym w debacie publicznej w Polsce. Zarówno politycy, dziennikarze, jak i eksperci, mimo powszechnej zgody co do korzyści i konieczności stosowania narzędzi elektronicznych w administracji publicznej, nie podjęli jak dotąd tematu wprowadzenia tej metody głosowania w wyborach. W związku z tym, że zagadnienie to nie było podejmowane, również $\mathrm{w}$ badaniach opinii publicznej ${ }^{1}$ wyraźnie brakowało informacji na ten temat" (s. 48-49).

Uzyskanie i zweryfikowanie opinii Polaków na temat e-votingu oraz odpowiedzi na pytanie o wpływ zmian wywołanych wykorzystaniem nowych technologii na procesy wyborcze wymagało: 1) przygotowania kwestionariusza ankiety (14 pytań merytorycznych, sześć pytań metryczkowych - płeć, wiek, wykształcenie, miejsce zamieszkania, województwo, status zawodowy) oraz przeprowadzenia badania ankietowego (między kwietniem i czerwcem 2018); 2) doboru próby osób (próba liczyła 1716 Polaków dobranych w sposób kwotowy z uwzględnieniem cech demograficznych populacji); 3) zastosowania

\footnotetext{
${ }^{1}$ Centrum Badania Opinii Publicznej (CBOS) przeprowadziło analizę opinii Polaków na temat głosowania elektronicznego w 2014 r. i w 2019 r.
} 
zróżnicowanych metod i narzędzi, które stały się podstawą przeprowadzonej analizy (analiza ilościowa, jakościowa, analiza danych statystycznych zgromadzonych podczas badań ankietowych, instytucjonalno-prawna, genetyczna metoda historyczna).

Zastosowanie metodologii z zakresu nauki o polityce także determinowało weryfikację dwóch głównych hipotez badawczych: „1) Postawy i opinie Polaków na temat głosowania elektronicznego oraz wykorzystania tego narzędzia w wyborach różnią się w zależności od wybranych demograficznych cech respondentów (s. 56); 2) Postawy i opinie Polaków na temat głosowania elektronicznego oraz wykorzystania tego narzędzia w wyborach są zależne od wybranych zmiennych politycznych" (s. 57). W przypadku pierwszej hipotezy za szczególnie istotne uznano takie zmienne jak: wiek, wykształcenie oraz miejsce zamieszkania. Ponadto sformułowano pięć hipotez pomocniczych skupionych na tych zmiennych. W odniesieniu do drugiej głównej hipotezy za istotne uznano odmienności, mogące występować w różnych grupach rozpatrywanych w kontekście: preferencji partyjnych, poglądów politycznych, systematyczności udziału (głosowania) w wyborach do Sejmu i Senatu. W tym przypadku sformułowano trzy hipotezy pomocnicze.

Równie istotna jest prawidłowa struktura treści książki. Realizacja założeń badawczych podyktowała podział treści na trzy rozdziały poprzedzone Wstępem. Pierwszy rozdział: Glosowanie elektroniczne jako przedmiot badań ma charakter teoretyczny. W tej części pracy przedstawiono wpływ nowych technologii na demokrację, podstawy teoretyczne związane z elektronicznym głosowaniem, kluczowe definicje i motywy, którymi kierują się państwa wdrażające rozwiązania w tym zakresie oraz kwestie związane $\mathrm{z}$ głosowaniem elektronicznym w Polsce w kontekście legislacji oraz „pierwsze bardzo skromne polskie doświadczenia z próbami głosowania przez Internet” (s. 14). Drugi rozdział: Metodologia określa warsztat badawczy, hipotezy i pytania badawcze, a także metody analizy systemowej, na której oparto część empiryczną monografii. Rozdział zawiera również charakterystykę osób ankietowanych. Rozdział trzeci: Elektroniczne głosowanie $w$ opiniach Polaków. Analiza wyników badań ma charakter empiryczny. Odpowiedzi osób biorących udział w ankiecie były rozpatrywane w kontekście zmiennych socjodemograficznych (płeć, wiek, wykształcenie, miejsce zamieszkania, województwo, status zawodowy) oraz politycznych (sposób głosowania w wyborach 2015 r., poglądy polityczne, deklarowany sposób głosowania w momencie badania [wiosna/lato 2018], postawy względem głosowania przez Internet) udział w wyborach do Sejmu i Senatu. W rozdziale wskaźnik poparcia dla e-votingu został opracowany na podstawie wyników badania statystycznego. Rozdział trzeci, co jest zasadne, zajmuje dominującą pozycję w monografii pod względem wartości poznawczych i wielostronnych podejść analitycznych. Temu najbardziej interesującemu problemowi zarówno pod 
względem poznawczym, jak i utylitarnym autorka słusznie poświęciła 145 stron monografii (na 193 strony wszystkich rozdziałów). Struktura rozdziału pozwoliła na klarowne, czytelne i logiczne uszeregowanie pozyskanych wyników.

Zastosowany w publikacji problemowy układ treści pozwolił na wyraźne wyodrębnienie zasadniczych grup tematycznych, a zarazem zachowanie spójności względem podstawowego problemu badawczego. Przyjęta struktura książki umożliwiła uzyskanie odpowiedzi na następujące pytanie: w jaki sposób Internet wpływa na procesy demokratyczne (głównie wybory), a przede wszystkim, jakie opinie wyrażają Polacy na temat tej metody głosowania

Opracowanie kończą Wnioski (s. 210-219), gdzie na podstawie wyników przeprowadzonych badań zweryfikowano pozytywnie większość hipotez badawczych. Sformułowane wnioski pozwoliły nakreślić portret zwolenników i przeciwników głosowania elektronicznego w Polsce. Dopełnieniem monografii są: cztery rysunki (rozdz. pierwszy), 24 tabele (rozdz. trzeci), 99 wykresów (rozdz. drugi -6, rozdz. trzeci-93).

Z przeprowadzonych badań wynika, że zdecydowanie bardziej przychylne głosowaniu elektronicznemu oraz w większym stopniu skłonne do skorzystania z głosowania przez Internet są osoby: z młodszych grup wiekowych; z wykształceniem wyższym; pracujące na pełnym etacie lub prowadzące własną działalność gospodarczą; pracujące dorywczo; kontynuujące naukę w szkole lub studiujące w uczelni wyższej; mieszkające w miastach powyżej 20 tys. mieszkańców. Nie zaobserwowano natomiast istotnych różnic wynikających z zamieszkania w określonych województwach. Zdecydowanie przychylni głosowaniu elektronicznemu oraz w większym stopniu skłonni do skorzystania z głosowania przez Internet są wyborcy: ugrupowań politycznych, które popierają wprowadzenie głosowania elektronicznego w wyborach (przykładowo: zwolennicy Platformy Obywatelskiej, Nowoczesnej, Kukiz'15, Sojuszu Lewicy Demokratycznej, Partii Razem); ugrupowań skupiających elektorat do 39. roku życia (przykładowo: Korwin, Konfederacja, Nowoczesna, Platforma Obywatelska), o poglądach liberalnych (zwolennicy: wolności i praw jednostki, ograniczenia ingerencji państwa w życie społeczno-gospodarcze).

Monografia Magdaleny Musiał-Karg jest bogatym kompendium wiedzy na temat głosowania elektronicznego jako przedmiotu badań naukowych, a zarazem głęboką diagnozą określającą wiedzę, opinie i oczekiwania polskich wyborców w kontekście korzyści, trudności oraz wyzwań stojących przed współczesną demokracją w obliczu jej nowej, wciąż zmieniającej się elektronicznej formy. Analiza postaw i poglądów odnośnie do wprowadzenia głosowania elektronicznego respondentów oraz ich deklaracje dotyczące chęci skorzystania z tej formy udziału w elekcjach państwowych mogą także określać kierunki rozwoju elektronicznej partycypacji w Polsce. Wyrażam przekonanie, że monografia ta spotka się z uznaniem profesjonalistów, praktyków życia poli- 
tycznego, tworzących prawo wyborcze, dziennikarzy, studentów nauk społecznych i szerszego grona czytelników. Przemawia za tym aktualna i interesująca poznawczo treść pracy, komunikatywny język, jasność narracji, a także staranna forma edytorska wydania.

Wskazane wartości poznawcze i metodologiczne monografii stanowią istotny argument do szerszego jej wykorzystania w kształtowaniu życia politycznego III RP.

Krystyna Leszczyńska-Wichmanowska

(iD) https://orcid.org/0000-0003-1459-9280 